\title{
Growth Model and Metabolic Activity of Brewing Yeast Biofilm on the Surface of Spent Grains: A Biocatalyst for Continuous Beer Fermentation
}

\author{
Tomáš Brányik, António A. Vicente, Gabriela Kuncová, Ondřej Podrazký, \\ Pavel Dostálek, and José A. Teixeira*
}

Centro de Engenharia Biológica, Universidade do Minho, Campus de Gualtar, 4710-057 Braga, Portugal, Institute of Chemical Process Fundamentals, Academy of Sciences, Rozvojová 135, 16502 Prague 6, Czech Republic, and Institute of Chemical Technology, Department of Fermentation Chemistry and Bioengineering, Technická 5, 166 28, Prague 6, Czech Republic

\begin{abstract}
In the continuous systems, such as continuous beer fermentation, immobilized cells are kept inside the bioreactor for long periods of time. Thus an important factor in the design and performance of the immobilized yeast reactor is immobilized cell viability and physiology. Both the decreasing specific glucose consumption rate $\left(q_{\mathrm{im}}\right)$ and intracellular redox potential of the cells immobilized to spent grains during continuous cultivation in bubble-column reactor implied alterations in cell physiology. It was hypothesized that the changes of the physiological state of the immobilized brewing yeast were due to the aging process to which the immobilized yeast are exposed in the continuous reactor. The amount of an actively growing fraction $\left(X_{\mathrm{im}}^{\text {act }}\right)$ of the total immobilized biomass $\left(X_{\mathrm{im}}\right)$ was subsequently estimated at approximately $X_{\mathrm{im}}^{\text {act }}=$ $0.12 \mathrm{~g}_{\mathrm{IB}} \mathrm{g}_{\mathrm{C}}^{-1}$ (IB = dry immobilized biomass, $\mathrm{C}=$ dry carrier). A mathematical model of the immobilized yeast biofilm growth on the surface of spent grain particles based on cell deposition (cell-to-carrier adhesion and cell-to-cell attachment), immobilized cell growth, and immobilized biomass detachment (cell outgrowth, biofilm abrasion) was formulated. The concept of the active fraction of immobilized biomass $\left(X_{\mathrm{im}}^{\text {act }}\right)$ and the maximum attainable biomass load $\left(X_{\mathrm{im}}^{\max }\right)$ was included into the model. Since the average biofilm thickness was estimated at ca. $10 \mu \mathrm{m}$, the limitation of the diffusion of substrates inside the yeast biofilm could be neglected. The model successfully predicted the dynamics of the immobilized cell growth, maximum biomass load, free cell growth, and glucose consumption under constant hydrodynamic conditions in a bubble-column reactor. Good agreement between model simulations and experimental data was achieved.
\end{abstract}

\section{Introduction}

When cells come into contact with solid surfaces, a variety of interactions may lead to adhesion. The molecular mechanism of either yeast-to-yeast or yeast-tocarrier adhesion is rather complex, and although often contradictory, it is based mainly on physicochemical interactions $(1,2)$ and specific biochemical interactions $(3,4)$. In cell aggregation and flocculation, the role of the glycoprotein (zymolectins) structures on the surface of Saccharomyces cerevisiae yeast has been emphasized (5, 6 ). The mechanism of yeast adhesion to carrier surface has been based by various authors on hydrophobic interactions (7-9), but the exact mechanism is still a matter of controversy.

Systems in which cells are bound to nonporous surfaces $(10,11)$ are advantageous as a result of the ease of this type of immobilization and the lower mass transfer limitations of substrates and products in comparison to those of entrapped cells. Although the biofilm formation is in many places unwanted, it can also be exploited in

* To whom correspondence should be addressed. Ph: +351 253 604406. Fax: +351253 678986.E-mail: jateixeira@deb.uminho.pt. biotechnological processes, e.g., wastewater treatment (12), water purification (13), and ethanol production (14), offering advantages such as increased process flow rates without washing the organisms from the reactor. However, the success of this method depends on the strength with which the cells are bound to the support, and therefore its use is not recommended where a cell-free effluent is desired (15). On the other hand, immobilized systems with cells in direct contact with the surrounding environment are capable of self-regeneration, i.e., to randomly shed immobilized biomass and incorporate young cells (16). In addition to the intensity of the attractive forces between cell and support, the biofilm thickness is influenced by feed rate, cell physiology, diffusion limitation of substrates, and hydrodynamic conditions in the reactor $(17,18)$. Therefore, it is difficult to predict and control the immobilized biofilm processes.

Besides the engineering advantages the immobilized biofilms offer, the cell contact with an insoluble support can have far-reaching consequences with regard to microbial metabolism. Experimental evidence ranges from altered optimal growth conditions, affected yields, product synthesis rates, and morphological changes to 
no detectable effect of the immobilization (19). Understanding the immobilized cell physiology is relevant for increasing the productivity of biotechnological processes by taking advantage of microbial biofilm formation.

The viability of immobilized yeast spending long periods of time in a bioreactor was observed to decrease (16). In addition to the environmental factors influencing the biocatalyst's performance, in the case of the eukaryotic cells (brewing yeast) it is the genetically dependent finite replicative lifespan that can also determine the cell viability $(20,21)$. Therefore, the prediction of the viable fraction of immobilized cells may be critical for correct bioreactor performance. $\mathrm{NAD}(\mathrm{P}) \mathrm{H}$ fluorosensor has successfully been used as a noninvasive, on-line method of monitoring freely suspended and immobilized yeast cell metabolism (22-24).

The intention of this work was to develop a simple kinetic model, based on mass balance equations, capable of predicting the immobilization of brewing yeast on spent grain particles, a biocatalyst successfully applied in continuous primary beer fermentation $(25,26)$. Because the long-term stability of the biocatalyst is crucial for continuous beer fermentation $(27,28)$, it was necessary to estimate the metabolic state of the immobilized brewing yeast. The hypothesis that as a result of the finite replicative lifespan of the brewing yeast there will be an active fraction of the total immobilized biomass responsible for growth and substrate consumption was examined, and this concept was incorporated into the kinetic model of the immobilized cell reactor.

\section{Matetrials and Methods}

Microorganism and Medium. The brewing yeast Saccharomyces pastorianus (carlsbergensis), kindly supplied by a brewing company (UNICER - Bebidas de Portugal, S.A., S. Mamede de Infesta, Portugal) was cultivated for inoculation of the bubble-column reactor in $100 \mathrm{~mL}$ of complete medium (CM) under aerobic conditions on a rotary shaker $(120 \mathrm{rpm})$ at $30{ }^{\circ} \mathrm{C}$ for 30 h. The CM contains $\left(\mathrm{g} \mathrm{L}^{-1}\right) \mathrm{KH}_{2} \mathrm{PO}_{4}, 5.0 ;\left(\mathrm{NH}_{4}\right)_{2} \mathrm{SO}_{4}, 2.0$; $\mathrm{MgSO}_{4} \cdot 7 \mathrm{H}_{2} \mathrm{O}, 0.4$; yeast extract, 1.0 ; glucose, 10.0 , and its $\mathrm{pH}$ was adjusted to 5.0 using $\mathrm{H}_{2} \mathrm{SO}_{4}$. A mineral medium (MM) without glucose and yeast extract for cell vitality measurements based on monitoring the changes of intracellular $\mathrm{NAD}(\mathrm{P}) \mathrm{H}$ fluorescence has also been used.

Carrier Preparation from Spent Grains. The acid/ base-treated carrier was prepared from dry spent grains $(100 \mathrm{~g})$ dispersed in $1500 \mathrm{~mL}$ of $3 \%(\mathrm{v} / \mathrm{v}) \mathrm{HCl}$ solution at $60{ }^{\circ} \mathrm{C}$ for $2.5 \mathrm{~h}$ in order to hydrolyze the residual starchy endosperm and embryo of the barley kernel present in the spent grains. The mixture was then cooled, washed with water, and dried. The remaining solids (ca. $30 \mathrm{~g}$ ), mainly the husks of the barley grain, were partially delignified by shaking (120 rpm) in $500 \mathrm{~mL}$ of $2 \%(\mathrm{w} / \mathrm{v})$ $\mathrm{NaOH}$ solution at $30^{\circ} \mathrm{C}$ for $24 \mathrm{~h}$. After being several times washed with water until $\mathrm{pH} 7$ (measured from bulk liquid with an indicator paper) and dried, the carrier (ca. $10 \mathrm{~g}$ ) was ready to be used.

Immobilization. Experiments with brewing yeast immobilization to spent grain particles were carried out during continuous brewing yeast cultivations in a bubblecolumn reactor. Three mechanisms of gradual brewing yeast immobilization onto spent grains carrier can be considered as earlier proposed: cell-to-carrier adhesion, cell-to-cell attachment, and cell adsorption (accumulation) inside natural shelters formed by carrier's surface roughness (7).

Batch Experiments. Two samples of biocatalyst (carrier + immobilized cells, ca. $0.2 \mathrm{~g}$ of dry biocatalyst) were taken through the outflow at 150 and $250 \mathrm{~h}$ of the continuous brewing yeast immobilization experiments $(D$ $=0.195 \mathrm{~h}^{-1}$ ) in order to compare the growth rates of immobilized and free cells. The excess of the bulk liquid with free cells was removed from the sample with a sterile syringe. The biocatalyst was transferred into 700 $\mathrm{mL}$ of sterile distilled water in a beaker in order to remove the rest of the free or loosely bound cells. Then the carrier particles with immobilized brewing yeast were allowed to settle and the cell suspension in the distilled water was removed. A small amount of biocatalyst (ca. $0.01 \mathrm{~g}$ in dry state) was used to inoculate $100 \mathrm{~mL}$ of CM in a 250 -mL Erlenmeyer flask. At the same time $100 \mathrm{~mL}$ of CM in a 250-mL Erlenmeyer flask was inoculated from an agar slant incubated for $12 \mathrm{~h}$ at $25{ }^{\circ} \mathrm{C}$. The growth curves of cells liberated from the biocatalyst and of the free cells from the agar slant were compared during batch cultivation on a rotary shaker $(140 \mathrm{rpm})$ at $25^{\circ} \mathrm{C}$.

Continuous Culture Experiments. All continuous experiments were carried out in a continuous bubblecolumn reactor with a total working volume of $440 \mathrm{~mL}$ (height-to-diameter ratio 1.5). The reactor was inoculated with $100 \mathrm{~mL}$ of precultured brewing yeast suspension and filled with CM. The continuous feed was started after $16 \mathrm{~h}$ of batch growth at dilution rates $(D)$ in the range $0.06-0.27 \mathrm{~h}^{-1}$. CM was supplied at the bottom of the reactor by means of a peristaltic pump (Watson Marlow 101 U/R, Falmouth, England). Sterile air was passed into the bubble column at $0.5 \mathrm{l} \mathrm{min}^{-1}$ through a distributor with four holes (1 $\mathrm{mm}$ in diameter each), and the temperature was maintained at $25^{\circ} \mathrm{C}$. Experiments with brewing yeast immobilization were carried out with ca. $6 \mathrm{~g}$ (dry weight) of spent grain carrier added before the inoculation into the reactor.

Detachment Experiments. Until 48 h of operation the detachment experiments were carried out in a similar way as the continuous experiments with a fixed CM feed rate $\left(D=0.27 \mathrm{~h}^{-1}\right)$. After this time the immobilized biomass load $\left(X_{\text {im }}\right)$ was between 0.02 and $0.03 \mathrm{~g}_{\mathrm{IB}} \mathrm{g}_{\mathrm{C}}{ }^{-1}$, and $D$ was increased to $1.15 \mathrm{~h}^{-1}$ and maintained throughout the detachment experiment without the risk of the immobilized cell washout. Concentrations of $X_{\mathrm{im}}$, free biomass $\left(X_{\text {free }}, \mathrm{g} \mathrm{L}^{-1}\right)$ in the reactor, and glucose $\left(S_{\mathrm{GLUC}}\right.$, $\mathrm{g} \mathrm{L}^{-1}$ ) in the outflow were monitored.

Immobilized Biomass Determination. A sample containing approximately $0.4 \mathrm{~g}$ of dry biocatalyst was taken from the reactor. The bulk liquid was removed with a syringe and the carrier was washed with $2 \times 100 \mathrm{~mL}$ of distilled water. The biocatalyst was then filtered and washed with $400 \mathrm{~mL}$ of distilled water on a paper filter and then dried at $105{ }^{\circ} \mathrm{C}$ for $12 \mathrm{~h}$. An amount of approximately $0.2 \mathrm{~g}$ dry biocatalyst was weighed into an Erlenmeyer flask with $50 \mathrm{~mL}$ of $3 \%(\mathrm{w} / \mathrm{v}) \mathrm{NaOH}$ solution and was shaken at $120 \mathrm{rpm}$ for $24 \mathrm{~h}$. During this time the immobilized cells were completely removed from the carrier, as was verified under the microscope. The cell free carrier was filtered, and after being carefully washed on the filter with $400 \mathrm{~mL}$ of distilled water it was dried at $105{ }^{\circ} \mathrm{C}$ for $5 \mathrm{~h}$. The amount of immobilized yeast biomass was determined from the weight difference before and after the treatment with caustic. Corrections of the biomass weight due to losses of the carrier itself were carried out by blank experiments with clean carrier.

Cell Vitality Monitoring. The change of $\mathrm{NAD}(\mathrm{P}) \mathrm{H}$ fluorescence intensity, measured at $340 / 460 \mathrm{~nm}$ (excitation/emission wavelength), as the response to aerobicanaerobic (AA) transition was considered a good indicator of the redox state of the immobilized cell (29). Biocatalyst (ca. $0.5 \mathrm{~g}$ of carrier with immobilized cells) was removed 


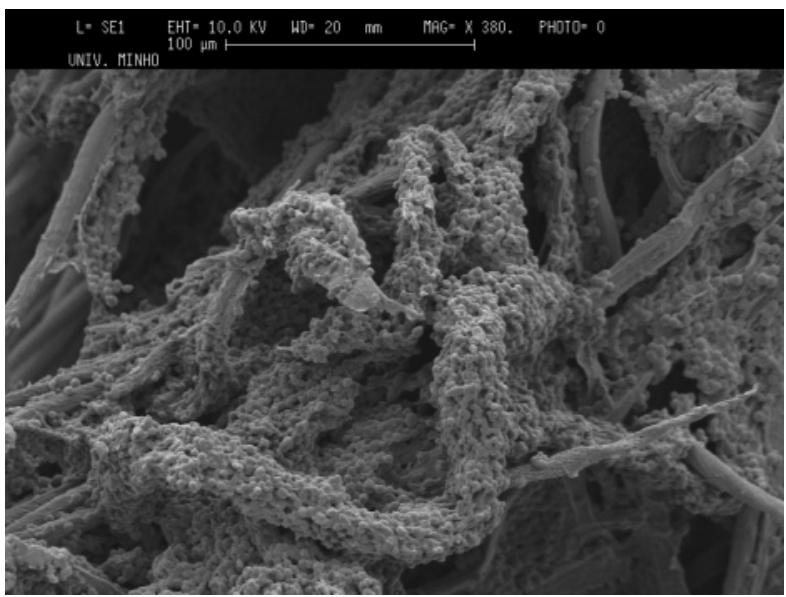

Figure 1. Photomicrograph (SEM) of carrier particles with immobilized yeast cells $\left(X_{\mathrm{im}}=0.4 \mathrm{~g}_{\mathrm{IB}} \mathrm{g}_{\mathrm{C}}{ }^{-1}\right)$. White bar corresponds to $100 \mu \mathrm{m}$.

from the continuous reactor $\left(D=0.23 \mathrm{~h}^{-1}\right)$, drained, and washed with $200 \mathrm{~mL}$ of mineral medium (MM). An aliquot $(0.025 \pm 0.002 \mathrm{~g}$ in dry state $)$ was placed into a flow-through chamber $\left(15 \times 5 \times 5 \mathrm{~mm}^{3}\right)$ with a quartz front window and aerated. MM $\left(30{ }^{\circ} \mathrm{C}\right)$ was pumped through the chamber $\left(12 \mathrm{~mL} \mathrm{~min}^{-1}\right)$ during $20 \mathrm{~min}$. When the culture fluorescence was considered to have reached steady-state conditions, the MM flow was stopped for 5 min. After this time the MM flow was turned on again, and when the fluorescence signal returned to steady state, the AA transition was repeated. $\mathrm{NAD}(\mathrm{P}) \mathrm{H}$ fluorescence signal was recorded on-line every $0.5 \mathrm{~s}$ using a Hitachi F-4500 fluorescence spectrophotometer (Hitachi, Japan). The measurements were performed in front-face setup in which the excitation beam impinges on the chamber front window at an angle of $30^{\circ}$. The fluorescence signal $\left(F_{\mathrm{NAD}(\mathrm{P}) \mathrm{H}}\right)$ was smoothed by a moving average data analysis tool, and its first derivative $(\mathrm{d} F / \mathrm{d} t)$ was used to evaluate the cells' metabolic activity.

Analytical and Computational Methods. Glucose concentration was determined by the DNS (3,5-dinitrosalicylic acid) method. Specific surface area of the carrier was determined with $\mathrm{N}_{2}$ according to BET (BrunauerEmmett-Teller) procedure (ASAP 2010M, Micromeretics, USA). The kinetic model was integrated in the computer program PSI V2.00a (Boza Automatisering BV, Nuenen, The Netherlands).

Scanning Electron Microscopy (SEM). A sample of the biocatalyst (ca. $0.2 \mathrm{~g}$ in dry state) was washed with $50 \mathrm{~mL}$ of distilled water and then with $20 \mathrm{~mL}$ of ethanol with increasing concentration $(10 \%, 25 \%, 50 \%, 75 \%, 90 \%$, and $100 \%)$. Finally the sample was dried for several days in a desiccator. The carrier with immobilized yeast was coated with a thin gold layer by vacuum evaporation, and subsequently the observations by scanning electron microscopy (SEM) were performed.

\section{Results}

Immobilized Biomass Growth. Biofilm formation by brewing yeast (Saccharomyces pastorianus) on carrier particles prepared from spent grains was studied in a continuously operating $440-\mathrm{mL}$ bubble-column reactor. Figure 1 shows threadlike spent grain particles partially covered by brewing yeast biofilm $\left(X_{\mathrm{im}}=\right.$ ca. $\left.0.4 \mathrm{~g}_{\mathrm{IB}} \mathrm{g}_{\mathrm{C}}{ }^{-1}\right)$. The overall results of immobilized biomass accumulation obtained at a dilution rate $D=0.24 \mathrm{~h}^{-1}$ are given in Figure 2. The progression of immobilized biofilm $\left(X_{\text {im }}\right)$ accumulation follows a typical sigmoid-shaped curve,

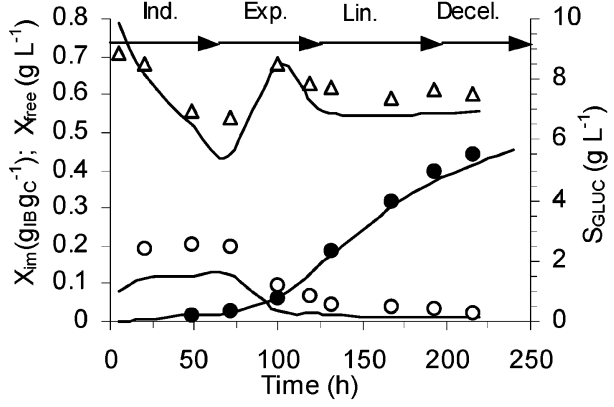

Figure 2. Immobilized biomass accumulation $\left(X_{\mathrm{im}}, \bullet\right)$, free biomass $\left(X_{\text {free }}, \Delta\right)$, and glucose concentration $\left(S_{\mathrm{GLUC}}, O\right)$ in the continuous bubble-column reactor at $D=0.24 \mathrm{~h}^{-1}$. Markers represent the experimental data and solid lines correspond to model simulations.

which can be divided into four phases, i.e., induction, exponential phase, linear phase, and deceleration (Figure 2 ), followed by a plateau (Figure 5). The induction phase starts at time zero and lasts until the lower detection limit of the immobilized biomass concentration in dry immobilized biomass (IB) weight per dry carrier (C) weight $\left(X_{\mathrm{im}}=0.03 \mathrm{~g}_{\mathrm{IB}} \mathrm{g}_{\mathrm{C}}{ }^{-1}\right)$ is reached. It is followed by the exponential accumulation phase finishing at approximately $X_{\mathrm{im}}=0.15 \mathrm{~g}_{\mathrm{IB}} \mathrm{g}_{\mathrm{C}}{ }^{-1}$ where the biomass accumulation starts to progress linearly (Figure 2). The continuous system can be considered in steady state when the glucose consumption gives rise to substrate limitation and the $X_{\text {im }}$ reaches the plateau. Another type of steady state can occur under substrate-sufficient conditions where the maximum immobilized biomass load $\left(X_{\mathrm{im}}^{\max }\right)$ will be controlled by the maximum mechanical strength of the yeast biofilm under given hydrodynamic conditions (Figure 5).

The availability of the substrate in the continuous system, increasing with $D$, brought about an acceleration of the immobilized biomass accumulation (Figure 3 ). Higher feed rate shortened the induction phase, increased the biofilm accumulation rate, and increased the maximum biomass load ( $\left.X_{\mathrm{im}}^{\mathrm{max}}\right)$ achievable in the system.

The influence of $D$ on cell adhesion during the induction phase resulted in a linear increase of the immobilized biomass deposition rate $\left(R_{\text {dep }}, \mathrm{g}_{\mathrm{IB}} \mathrm{g}_{\mathrm{C}}{ }^{-1} \mathrm{~h}^{-1}\right)$ defined as the rate of the biomass immobilization until the immobilized biomass load of $X_{\mathrm{im}}=0.03 \mathrm{~g}_{\mathrm{IB}} \mathrm{g}_{\mathrm{C}}{ }^{-1}$. It was calculated for continuous immobilization experiments at different $D$ using the induction times ( $\left.T_{\text {ind }}\right)$, a time period necessary to reach $X_{\mathrm{im}}=0.03 \mathrm{~g}_{\mathrm{IB}} \mathrm{g}_{\mathrm{C}}{ }^{-1}$, as follows: $R_{\text {dep }}=0.03 / T_{\text {ind }}$. On the contrary, the increasing concentration of free cells ( $X_{\text {free }}$ ) had no positive effect on $R_{\text {dep }}$ during the induction phase (Figure 4).

The growth curves of cells in batch experiments inoculated either by immobilized cells (biocatalyst), after 150 and $250 \mathrm{~h}$ in a continuous reactor $\left(D=0.195 \mathrm{~h}^{-1}\right)$, or free cells (agar slant) were very similar (data not shown). There was no difference in terms of maximum specific growth rate $\left(\mu_{\max }=0.285 \pm 0.002 \mathrm{~h}^{-1}\right)$ for the cells originated from the yeast immobilized on spent grains and yeast kept on agar slants.

Immobilized Biomass Detachment. The detachment and outgrowth rate of yeast from the immobilized biofilm was followed during detachment experiments carried out in the continuous reactor at high dilution rate $\left(D \gg \mu_{\max }\right)$. Since at $D=1.15 \mathrm{~h}^{-1}$ most of the free cells are washed out before they could multiply, the only free biomass $\left(X_{\text {free }}\right)$ in the reactor originates almost entirely from the immobilized biomass $\left(X_{\mathrm{im}}\right)$. It was found that 


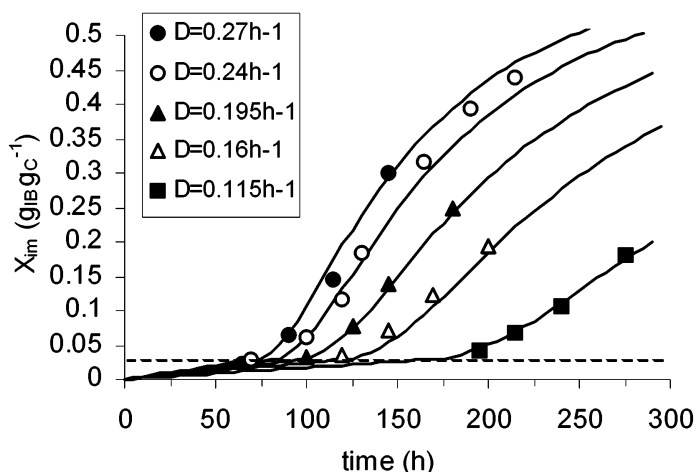

Figure 3. Immobilized biomass accumulation $\left(X_{\mathrm{im}}\right)$ on spent grain particles at different dilution rates $(D)$. Markers represent the experimental data, solid lines correspond to model simulations, and the dotted line represents the value $X_{\mathrm{im}}=0.03 \mathrm{~g}_{\mathrm{IB}}$ $\mathrm{g}_{\mathrm{C}}{ }^{-1}$.

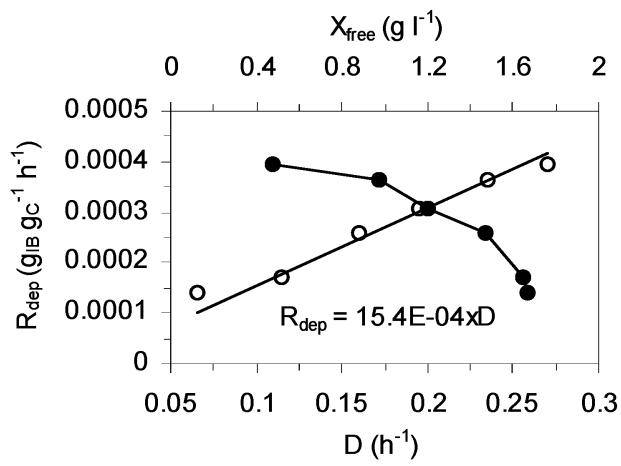

Figure 4. Immobilized biomass deposition rate $\left(R_{\text {dep }}\right)$ versus $(O)$ dilution rate $(D)$ and $(\bullet)$ free cell concentration during induction phase $\left(X_{\text {free }}\right)$.

the specific immobilized biomass detachment rate $\left(k_{\mathrm{det}}\right)$ first decreased significantly and then at steady state asymptotically approached the value of approximately $0.05 \mathrm{~h}^{-1}$ (Figure 5). The detachment rate $\left(R_{\mathrm{det}}, \mathrm{g}_{\mathrm{IB}} \mathrm{g}_{\mathrm{C}}{ }^{-1}\right.$ $\mathrm{h}^{-1}$ ) curve followed practically the same sigmoid shape as the curve of the immobilized biomass accumulation (data not shown).

From the known glucose consumption, the immobilized biomass concentration $\left(X_{\mathrm{im}}\right)$ and the applied $D$ it was possible to calculate the specific glucose consumption rate $\left(q_{\mathrm{im}}\right)$ of the immobilized biomass. The initial value of $q_{\mathrm{im}}$ (ca. $2.9 \mathrm{~g}_{\mathrm{GLUC}} \mathrm{g}_{\mathrm{IB}}{ }^{-1} \mathrm{~h}^{-1}$ ) was comparable with the maximum specific glucose consumption rate of the free cells (ca. $q_{\mathrm{free}}^{\max }=3.2 \mathrm{~g}_{\mathrm{GLUC}} \mathrm{g}_{\mathrm{FB}}{ }^{-1} \mathrm{~h}^{-1}$ ). However, the further increase of $X_{\mathrm{im}}$ resulted in a significant decrease of $q_{\mathrm{im}}$ (Figure 5).

Aerobic-Anaerobic Transition. The aerobic-anaerobic (AA) transitions were performed to characterize the immobilized cell metabolic activity (vitality). In the absence of extracellular carbon and energy source, as only mineral medium (MM) was circulating through the flowthrough chamber, the immobilized yeast cells were metabolizing their intracellular carbohydrate reserves (mainly glycogen). As a result of the MM flow stop, the fluorescence increased abruptly as the dissolved oxygen in the MM dropped to zero due to endogenous cell respiration (Figure 6). This effect is due to the increase in the level of intracellular $\mathrm{NAD}(\mathrm{P}) \mathrm{H}$, which cannot be oxidized through the respiration chain. The derivative of the fluorescence signal $(\mathrm{d} F / \mathrm{d} t)$ was then calculated from the $\mathrm{NAD}(\mathrm{P}) \mathrm{H}$ signal. When the maximum rates of fluorescence changes $\left(\mathrm{d} F / \mathrm{d} t^{\max }\right)$ were plotted against $X_{\mathrm{im}}$, the fluorescence signal dynamics increased until $X_{\mathrm{im}}=$

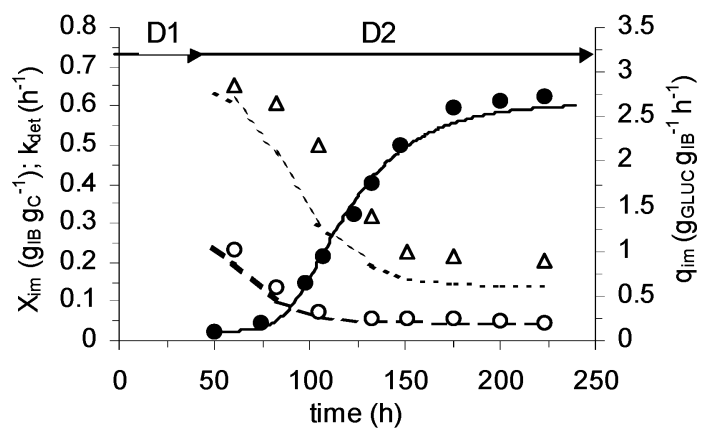

Figure 5. Immobilized biomass load accumulation $\left(X_{\mathrm{im}}, \bullet\right)$, specific immobilized biomass detachment rate $\left(k_{\text {det }}, 0\right)$, and specific glucose consumption rate of the immobilized yeast $\left(q_{\text {im }}\right.$, $\triangle$ ) during detachment experiment $\left(D_{1}=0.27 \mathrm{~h}^{-1}, D_{2}=1.15 \mathrm{~h}^{-1}\right)$. Markers represent the experimental data, and solid lines correspond to model simulations.

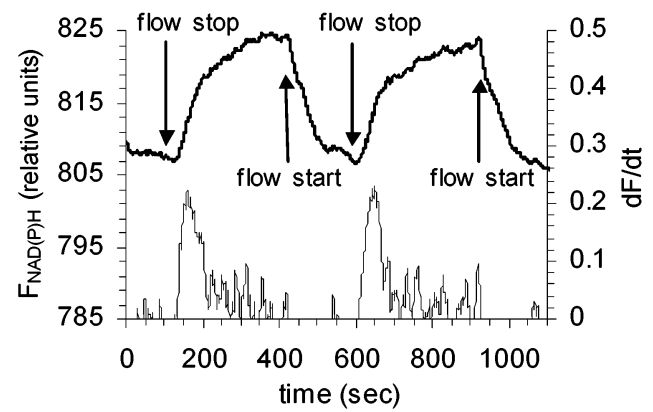

Figure 6. Changes of $\mathrm{NAD}(\mathrm{P}) \mathrm{H}$ fluorescence $\left(F_{\mathrm{NAD}(\mathrm{P}) \mathrm{H}}\right.$, thick line) of the immobilized cells as a result of AA transition and the first derivative of the signal $(\mathrm{d} F / \mathrm{d} t$, thin line). The arrows represent the stop or start of the MM flow.

$0.15 \mathrm{~g}_{\mathrm{IB}} \mathrm{g}_{\mathrm{C}}{ }^{-1}$. Starting from this $X_{\mathrm{im}}$ value, a further biomass accumulation on the surface of spent grain particles $\left(X_{\text {im }}\right)$ resulted in gradual decrease of $\mathrm{d} F / \mathrm{d} t^{\max }$ (Figure 7).

\section{Discussion}

Metabolic State of Immobilized Cells. The metabolic state of the brewing yeast immobilized on spent grain particles is not constant in time. The initial specific glucose consumption rate by the immobilized cells $\left(q_{\text {im }}\right)$, comparable with that of the free cells, did not remain constant during the immobilized biomass accumulation experiment (Figure 5). Similarly, the maximum rate of the intracellular $\mathrm{NAD}(\mathrm{P}) \mathrm{H}$ fluorescence changes, provoked by AA transitions, increased together with the increase of $X_{\mathrm{im}}$ only until $0.15 \mathrm{~g}_{\mathrm{IB}} \mathrm{g}_{\mathrm{C}}{ }^{-1}$, after which it decreased (Figure 7). Although the attenuating effect of media composition and biomass growth on $\mathrm{NAD}(\mathrm{P}) \mathrm{H}$ fluorescence (inner filter effect) cannot be completely eliminated by the front-face setup and signal derivation, it is possible to correlate the $\mathrm{d} F / \mathrm{d} t^{\max }$ with the viable cell count (30). Thus, both $q_{\text {im }}$ and $\mathrm{d} F / \mathrm{d} t^{\max }$ changes suggest alterations in immobilized cell physiology during the continuous culture experiment.

The changes of the physiological state of the immobilized cells can be ascribed to the aging process to which the immobilized cells are exposed in the continuous reactor, unlike the free cell population, which can be considered homogeneous in terms of cell age. The decrease of $\mathrm{d} F / \mathrm{d} t^{\max }$ started after ca. $115 \mathrm{~h}\left(D=0.23 \mathrm{~h}^{-1}\right)$ of reactor operation (data not shown), corresponding to approximately 30 cell cycles at the respective cell growth rate. Assuming that the brewing yeasts possess a finite replicative lifespan $(20,31)$, the existence of an actively 


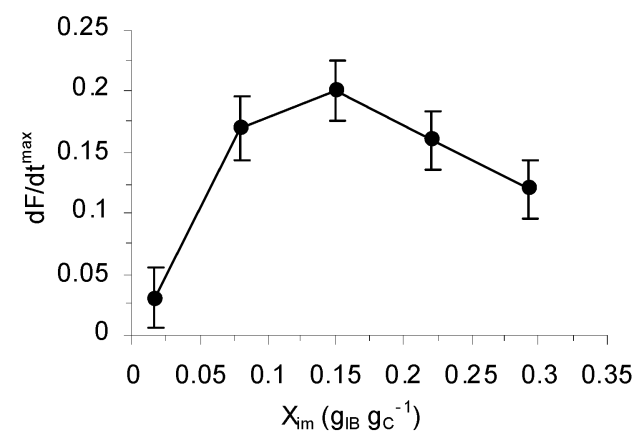

Figure 7. The maximum of the fluorescence signal derivative $\left(\mathrm{d} F / \mathrm{d} t^{\max }\right)$ of the immobilized yeast during AA transition versus immobilized biomass load $\left(X_{\mathrm{im}}\right)$ in the continuous reactor $(D=$ $0.23 \mathrm{~h}^{-1}$ ).

growing fraction "active layer" $\left(X_{\mathrm{im}}^{\mathrm{act}}\right)$ of the total immobilized biomass $\left(X_{\mathrm{im}}\right)$, located in the outer part of the biofilm, can be hypothesized.

The estimation of $X_{\text {im }}^{\text {act }}$ value was based on the assumption of a steady-state biofilm $\left(\mathrm{d} X_{\mathrm{im}} / \mathrm{d} t=0\right)$ at the end of the detachment experiment (Figure 5) where the immobilized biomass detachment and growth rate exactly balance each other $\left(R_{\mathrm{grw}}=R_{\mathrm{det}}\right)$. In other words, the immobilized biomass detachment rate $\left(R_{\text {det }}=k_{\text {det }} \times X_{\text {im }}\right.$ $=0.05 \times 0.62=0.031 \mathrm{~g}_{\mathrm{IB}} \mathrm{g}_{\mathrm{C}}^{-1} \mathrm{~h}^{-1}$ ) from the total immobilized biomass is equal to the net biomass synthesis at maximum specific growth rate (no substrate limitation during detachment experiments) in the active fraction (layer) of the biofilm $\left(R_{\text {grw }}=\mu_{\mathrm{im}}^{\max } \times X_{\mathrm{im}}^{\mathrm{act}}\right)$. Assuming that $\mu_{\mathrm{im}}^{\max }=\mu_{\text {free }}^{\max }=0.29 \mathrm{~h}^{-1}$, as proved by batch experiments, and neglecting the cell deposition rate $\left(R_{\text {dep }}\right)$, due to low $X_{\text {free }}$ at high $D\left(1.15 \mathrm{~h}^{-1}\right)$, the steadystate value of $X_{\mathrm{im}}^{\text {act }}$ was estimated at $0.11 \mathrm{~g}_{\mathrm{IB}} \mathrm{g}_{\mathrm{C}}{ }^{1-}$. The $X_{\mathrm{im}}^{\text {act }}$ value estimated from the immobilized biomass load at the moment of the $\mathrm{d} F / \mathrm{d} t^{\max }$ decrease was somewhat higher, $X_{\mathrm{im}}^{\text {act }}=0.15 \mathrm{~g}_{\mathrm{IB}} \mathrm{g}_{\mathrm{C}}^{-1}$ (Figure 7).

In the first approximation the population of immobilized cells was sorted into two groups, actively growing $\left(X_{\mathrm{im}}^{\text {act }}\right)$ and nonproliferating cells. However, this approach did not take into account that the replicatively deactivated cells may retain their metabolic functions for prolonged periods of time (21).

Considering the yield coefficients of reductive (fermentation) and oxidative (respiration) glucose consumption to be 0.05 and 0.49 (32), respectively, the $Y_{\mathrm{X} / \mathrm{S}}=0.09$ determined from both batch and continuous free cell cultures (data not shown) suggests a prevailing fermentative metabolism of brewing yeast. The glucose consumption for maintenance purposes, estimated from continuous free cell cultures (33), was $m=0.15 \mathrm{~g}_{\mathrm{GLUC}}$ $\mathrm{g}_{\mathrm{FB}}{ }^{-1} \mathrm{~h}^{-1}$ ( $\mathrm{FB}=$ free biomass $)$.

Kinetic Model of Immobilized Biomass Accumulation. The rate of the immobilized yeast biofilm development is a result of a balance between cell deposition rate $\left(R_{\text {dep }}\right)$, immobilized biomass growth rate $\left(R_{\text {grw }}\right)$, and immobilized biomass detachment rate $\left(R_{\text {det }}\right)$. The immobilized cell growth and the yeast biofilm detachment can be further characterized by the specific growth rate of the immobilized biomass $\mu_{\mathrm{im}}\left(\mathrm{h}^{-1}\right)$ and the specific immobilized biomass detachment rate $k_{\text {det }}\left(\mathrm{h}^{-1}\right)$, respectively. The overall mass balance for $X_{\text {im }}$ can thus be expressed as

$$
\begin{aligned}
\frac{\mathrm{d} X_{\mathrm{im}}}{\mathrm{d} t}=R_{\mathrm{dep}}+R_{\mathrm{grw}}-R_{\mathrm{det}} & = \\
& R_{\mathrm{dep}}+\mu_{\mathrm{im}} X_{\mathrm{im}}-k_{\mathrm{det}} X_{\mathrm{im}}
\end{aligned}
$$

However, eq 1 does not take into account some important phenomena occurring during the continuous experiments, i.e., changes in the growth rate and metabolic activity (aging) of the immobilized cells, maintenance requirements, and the finite stability of the biofilm. Therefore a more complex kinetic model describing the variations of $X_{\mathrm{im}}, X_{\text {free, }}$, and glucose in the continuous immobilized cell system has been developed:

$$
\begin{gathered}
\frac{\mathrm{d} X_{\mathrm{im}}}{\mathrm{d} t}=X_{\mathrm{dep}}\left(1-\frac{X_{\mathrm{im}}}{X_{\mathrm{im}}^{\mathrm{max}}}\right) D+\mu_{\mathrm{im}}\left(\frac{X_{\mathrm{im}}^{\mathrm{act}}}{X_{\mathrm{im}}^{\mathrm{act}}+X_{\mathrm{im}}}\right) X_{\mathrm{im}}- \\
\frac{k_{\mathrm{det}}^{*}\left(\frac{X_{\mathrm{im}}^{\mathrm{act}}+X_{\mathrm{im}}}{X_{\mathrm{im}}}\right) X_{\mathrm{im}}}{\mathrm{d} t}=D\left(S_{0}-S\right)-\left(\frac{\mu_{\mathrm{im}}}{Y_{\mathrm{X} / \mathrm{S}}^{\mathrm{im}}}\right)\left(\frac{X_{\mathrm{im}}^{\mathrm{act}}}{X_{\mathrm{im}}^{\mathrm{act}}+X_{\mathrm{im}}}\right)\left(\frac{X_{\mathrm{im}} P_{\mathrm{c}}}{V_{\mathrm{r}}}\right)- \\
\frac{m\left(\frac{X_{\mathrm{im}} P_{\mathrm{c}}}{V_{\mathrm{r}}}\right)-\left(\frac{\mu_{\mathrm{free}}}{Y_{\mathrm{X} / \mathrm{S}}^{\text {free }}}\right)}{\mathrm{d} X_{\text {free }}}=\left(\mu_{\mathrm{free}}-D\right) X_{\mathrm{free}}+k_{\mathrm{det}}^{*}\left(\frac{X_{\mathrm{im}}^{\mathrm{act}}+X_{\mathrm{im}}}{X_{\mathrm{im}}}\right)\left(\frac{X_{\mathrm{im}} P_{\mathrm{c}}}{V_{\mathrm{r}}}\right)- \\
\left.k_{\mathrm{det}}^{*}=k_{\mathrm{det}}^{\mathrm{sst}} \frac{S+K_{\mathrm{S}}}{X_{\mathrm{im}}} X_{\mathrm{im}}^{\mathrm{max}}\right) D \\
\mu_{\mathrm{im} / \text { free }}=\mu_{\mathrm{im} / \text { free }}^{\text {max }} \frac{S}{S+K_{\mathrm{S}}}
\end{gathered}
$$

Taking into account the determined carrier surface area of $0.38 \pm 0.015 \mathrm{~m}^{2} \mathrm{~g}^{-1}$, the full biomass loading $X_{\mathrm{im}}^{\max }=0.62 \mathrm{~g}_{\mathrm{IB}} \mathrm{g}_{\mathrm{C}}{ }^{-1}$, the cell water content $70 \mathrm{wt} \%$, the yeast floc density $\rho=1033 \mathrm{~kg} \mathrm{~m}^{-3}(34)$, and porosity $\epsilon=$ 0.5 (35) adapted for yeast biofilm, it has been possible to estimate the maximum average biofilm thickness at ca. $10 \mu \mathrm{m}$. Although the biofilm thickness over the spent grain particles is not homogeneous, the penetration depth of both oxygen and glucose is significantly higher than the estimated maximum average biofilm thickness (35), rendering insignificant the diffusion limitations inside the biofilm. Here, penetration depth is defined as the distance, measured from the surface of the biofilm, corresponding to a volume of cells that are capable of consuming solute (oxygen or glucose) at a rate equal to the solute mass transfer rate at the surface of the biofilm. Therefore a kinetic model describing the mass balance of $X_{\mathrm{im}}$ does not need to incorporate limitation of the diffusion of substrates inside the yeast biofilm. In addition to this, the external mass transfer rate can be considered, for the hydrodynamic conditions (turbulent flow) in the reactor, as not limiting as well.

The kinetic model expressed in eqs 2-6 was used to predict the changes of $X_{\mathrm{im}}, X_{\text {freee }}$, and $S_{\mathrm{GLUC}}$ in the continuous immobilized cell reactor. During the induction phase of the biomass accumulation ( $X_{\text {im }}$ from 0 to 0.03 $\mathrm{g}_{\mathrm{IB}} \mathrm{g}_{\mathrm{C}}{ }^{-1}$ ) it was only the cell deposition (first term of eq 2 ) that was taken into account in the modeling of the biomass accumulation process. Starting from $X_{\text {im }}=0.03$ $\mathrm{g}_{\mathrm{IB}} \mathrm{g}_{\mathrm{C}}{ }^{-1}$ the whole kinetic model, using the parameters in Table 1, shows a good agreement with the experimental data (Figures 2 and 3). The slightly higher experimental values can be explained by the disturbed material 
Table 1. List of Model Parameters, Their Description, Values, and Units

\begin{tabular}{lll}
\hline parameter & \multicolumn{1}{c}{ description } & \multicolumn{1}{c}{ value/units } \\
\hline$X_{\mathrm{dep}}$ & cell deposition coefficient & $0.00154 \mathrm{~g}_{\mathrm{IB}} \mathrm{g}_{\mathrm{C}}{ }^{-1}$ \\
$X_{\mathrm{im}}^{\max }$ & maximum biofilm concentration & $0.62 \mathrm{~g}_{\mathrm{IB}} \mathrm{g}_{\mathrm{C}}{ }^{-1}$ \\
$\mathrm{X}_{\mathrm{im}}^{\text {act }}$ & active biofilm concentration & $0.12 \mathrm{~g}_{\mathrm{IB}} \mathrm{g}_{\mathrm{C}}{ }^{-1}$ \\
$\mu_{\mathrm{im} / \mathrm{m}}^{\max }$ & maximum specific growth rate & $0.29 \mathrm{~h}^{-1}$ \\
$k_{\mathrm{det}}^{\mathrm{sst}}$ & specific steady-state & $0.04 \mathrm{~h}^{-1}$ \\
$Y_{\mathrm{X} / \mathrm{S}}^{\mathrm{im} / \text { dree }}$ & detachment rate & \\
$m$ & maield coefficient & 0.09 \\
$S_{0}$ & influent glucose concentration & $0.15 \mathrm{~g}_{\mathrm{GLUC}} \mathrm{g}_{\mathrm{FB}}^{-1} \mathrm{~h}^{-1}$ \\
$K_{\mathrm{S}}$ & half-saturation constant & $0.3 \mathrm{~g} \mathrm{~L} \mathrm{~L}^{-1}$ \\
$P_{\mathrm{c}}$ & total dry carrier weight & $6 \mathrm{~g}$ \\
$V_{\mathrm{r}}$ & total reactor volume & $0.44 \mathrm{~L}^{-1}$ \\
$D$ & dilution rate & $0.06-1.15 \mathrm{~h}^{-1}$
\end{tabular}

balance due to samples of biocatalyst taken for $X_{\text {im }}$ determination.

Under excessive glucose concentration, e.g., the detachment experiment $\left(D=1.15 \mathrm{~h}^{-1}\right)$, the parameters $\mu_{\mathrm{im}}$ and $k_{\text {det }}^{*}$ in eq 2 can be replaced by $\mu_{\mathrm{im}}^{\max }\left(0.29 \mathrm{~h}^{-1}\right)$ and $k_{\text {det }}^{\text {sst }}\left(0.04 \mathrm{~h}^{-1}\right)$, respectively, and the cell deposition can be neglected due to low $X_{\text {free }}$ in the reactor. The model simulation of the biomass accumulation (initial $X_{\mathrm{im}}=$ $0.024 \mathrm{~g}_{\mathrm{IB}} \mathrm{g}_{\mathrm{C}}{ }^{-1}$ ) and specific immobilized biomass detachment rate $\left(k_{\mathrm{det}}=k_{\mathrm{det}}^{\text {sst }}\left(X_{\mathrm{im}}^{\mathrm{act}}+X_{\mathrm{im}}\right) / X_{\mathrm{im}}\right)$ shows a very good agreement with the experimental data (Figure 5). The model gives also a reasonable prediction of the specific glucose consumption rate by immobilized biomass $\left(q_{\mathrm{im}}\right)$ but slightly lower than the experimental values (Figure 5 ). The difference can be attributed to substrate overutilization (energy uncoupling) observed in glucosesufficient cultures (36), which is the case of the detachment experiment.

Cell Deposition. The cell deposition on the surface of spent grains involves various processes such as reversible cell-carrier adhesion, cell-cell attachment, and cell adsorption (pores, crevices), which are determined by physicochemical and biochemical characteristics of both cell and carrier surfaces. In addition, it is difficult to separate the contribution of growth and detachment from the deposition rate $\left(R_{\text {dep }}\right)$ during the initial phase of the biomass immobilization characterized by $X_{\mathrm{im}}$ value lower than $0.03 \mathrm{~g}_{\mathrm{IB}} \mathrm{g}_{\mathrm{C}}{ }^{-1}$. Since a positive effect of $D$ on $R_{\text {dep }}$ was found, indicating the possible role of selection pressure in the continuous system (Figure 4), an empirical term was used to describe cell deposition $\left(R_{\mathrm{dep}}=X_{\mathrm{dep}} D\right)$. This term is believed to govern the biomass accumulation process until the biomass load of $X_{\mathrm{im}}=0.03 \mathrm{~g}_{\mathrm{IB}} \mathrm{g}_{\mathrm{C}}{ }^{-1}$. The cell deposition coefficient $\left(X_{\text {dep }}\right)$ can be considered as a measure of attraction (stickiness) between carrier and cells. Further, the term $\left(1-X_{\mathrm{im}} / X_{\mathrm{im}}^{\max }\right)$ was added into $R_{\text {dep }}$ in order to express its decrease due to reduction of available carrier surface area as $X_{\mathrm{im}}$ approaches full loading $\left(X_{\mathrm{im}}^{\max }\right)$. The existence of a maximum mechanical stability of the yeast biofilm on spent grains was proved also during substrate-sufficient beer fermentation where $X_{\mathrm{im}}^{\max } \operatorname{did}$ not exceed $0.63 \mathrm{~g}_{\mathrm{IB}} \mathrm{g}_{\mathrm{C}}^{-1}(26)$.

Immobilized Cell Growth. In view of the aging and senescence of immobilized brewing yeast, the existence of an actively growing fraction $\left(X_{\mathrm{im}}^{\text {act }}\right)$ of the total immobilized biomass $\left(X_{\mathrm{im}}\right)$ was hypothesized and introduced into mass balance equations 2 and 3 . Contrary to other biofilm growth models $(37,38)$ this approach does not contain a separate term for cell inactivation. Instead, the changes of the immobilized biomass growth rate $\left(R_{\text {grw }}\right)$ were expressed through the decreasing portion of the growing immobilized cells from the total number of immobilized cells via term $X_{\mathrm{im}}^{\text {act }} /\left(X_{\mathrm{im}}^{\text {act }}+X_{\mathrm{im}}\right)$ in eq 2 . At low $X_{\mathrm{im}}$ the term in brackets attached to $R_{\text {grw }}$ (eq 2) is close to 1 , meaning that all of the immobilized biomass is able to grow and the immobilized biomass growth rate $\left(R_{\text {grw }}\right)$ can be only substrate-limited. In the course of the $X_{\mathrm{im}}$ growth, the decreasing values of the term $X_{\mathrm{im}}^{\text {act }} /\left(X_{\mathrm{im}}^{\text {act }}\right.$ $+X_{\mathrm{im}}$ ) express the increasing portion of the replicatively deactivated (senescent and dead) cells of the biofilm, which does not contribute to $R_{\text {grw }}$. The viable immobilized biomass fraction $\left(X_{\mathrm{im}}^{\text {act }}=0.12 \mathrm{~g}_{\mathrm{IB}} \mathrm{g}_{\mathrm{C}}{ }^{-1}\right)$ was considered constant throughout the simulation of the biomass accumulation. However, its value will be certainly influenced by the replicative lifetime of the applied microorganism, cultivation conditions, and hydrodynamics in the reactor.

Whether the lifetime of the actively growing biofilm fraction $\left(X_{\mathrm{im}}^{\text {act }}\right)$ becomes gradually exceeded after $X_{\mathrm{im}}^{\max }$ was reached or can be considered constant during a longterm utilization of the biocatalyst $(25,26)$, depends on the self-regeneration ability of the fully developed brewing yeast biofilm. The self-regeneration ability of a bacterial biofilm is based on the spontaneous biofilm detachment and subsequent recolonization of carrier (39). Brányik et al. (25) showed that the brewing yeast biofilms were capable of recovering from process upsets by replacing the lost immobilized biomass.

Immobilized Cell Detachment. In the kinetic model of brewing yeast accumulation on the surface of spent grain particles a first-order dependence of detachment rate $\left(R_{\text {det }}\right)$ on biofilm mass was applied (eq 2 ). The detachment of the immobilized cells consists of processes such as outgrowth of the immobilized cells, sloughing, and abrasion (40). Although sloughing can be neglected because of small biofilm thickness (ca. $10 \mu \mathrm{m}$ ), abrasion is influenced by the biofilm thickness, degree of carrier colonization, hydrodynamic conditions, reactor design, substrate load, carrier roughness, microorganism, biofilm mechanical strength, etc. $(37,39,41)$. Therefore, the specific steady-state detachment rate $\left(k_{\text {det }}^{\text {sst }}\right)$ estimated from the results of the detachment experiments, containing the contribution of both outgrowth and abrasion, is valid only at constant hydrodynamic conditions and reactor design applied in this work.

Because the immobilized cell detachment in this system is also a growth-associated phenomenon, it is a function of local cellular physiology in the biofilm. To express the influence of aging and substrate-limited growth of immobilized biomass on the detachment rate, the concept of an actively growing biomass fraction as a part of the term $\left(X_{\mathrm{im}}^{\mathrm{act}}+X_{\mathrm{im}}\right) / X_{\mathrm{im}}$ (eq 2) and specific detachment rate coefficient $\left(k_{\text {det }}^{*}\right)$ following Monod kinetics (eq 6) was built into the model, respectively. The term $\left(X_{\mathrm{im}}^{\text {act }}+X_{\mathrm{im}}\right) / X_{\mathrm{im}}$ was designated to express the decreasing portion of growing immobilized cells from the total immobilized biomass participating on the outgrowth during the development of $X_{\mathrm{im}}$.

Besides the processes mentioned above, the selective pressure of the continuous system, creating an advantage for the free cells able to adhere to spent grains carrier, can influence the biomass detachment as well. From this viewpoint, the initial decrease of $k_{\text {det }}$ (Figure 5) can be conceived as an increase in the irreversibility of the cellto-carrier adhesion. Although the possible selection might have resulted in a subpopulation with altered surface properties (7), facilitating the adhesion to the carrier, no 
effect of selection on the maximum specific growth rate of the immobilized cell $\left(\mu_{\mathrm{im}}^{\max }\right)$ has been observed.

The dynamic equilibrium between spontaneous detachment (sloughing) of the fully developed biofilm and subsequent replacement of the biofilm often results in a quasi-steady state with fluctuations of the biofilm thickness $(37,38)$. The fact that there were no significant oscillations of the brewing yeast biofilm observed in the course of the long-term brewing experiments (26) clearly indicates the absence of significant biofilm sloughing. However, the brewing yeast biofilm proved to be sensitive toward sudden changes of hydrodynamic conditions in an airlift reactor $(25,26)$. Therefore, the biocatalyst lifetime could be prolonged and its physiological state improved by increasing the intensity of interphase transport of biomass particles between the microbial film and the fluid phase surrounding the film. In the case of bacterial biofilm it could be achieved either by decreasing the cohesiveness (stability) of the biofilm deposit through lower fluid velocities during the biofilm growth (42) or by short but regular and intensive increase of gas velocity in the reactor (43). However, the result of the first suggested approach is in the case of yeast cells questionable, and the latter could undesirably influence foaming and product quality during beer fermentation.

For practical brewing applications though, a regular replacement of the part of the "old" biocatalyst by clean spent grains carrier, added in the form of a sterilized slurry made of carrier suspended in water, can be considered as an acceptable alternative. The new (clean) carrier obtained either from spent grains or by recycling (washing in caustic and sterilization) the used biocatalyst (10) was shown to be readily colonized by free brewing yeast $(26)$.

\section{Conclusions}

A kinetic model for brewing yeast immobilization on spent grain particles, free cell growth, and glucose consumption in a continuous bubble-column reactor has been proposed. The model was based on the assumption that the net yeast biofilm accumulation is mainly a result of cell adsorption (attachment), growth, and detachment of immobilized cells. Observations of the decreasing metabolic activity (specific glucose consumption rate, redox state) of the immobilized biomass and the finite replicative lifespan of the eukaryotic brewing yeast led to the hypothesis of a viable fraction of the total immobilized biomass. Thus, the mass balance equations for the simulation of biofilm development were extended by the concept of the actively growing fraction of the total immobilized biomass. The proposed model satisfactorily described yeast biofilm development on the surface of spent grains under constant hydrodynamic conditions in a bubble-column reactor. Using this model, it was possible to predict the rate of the brewing yeast immobilization and the maximum immobilized biomass load at different feed rates creating either substrate-limited or substrate-sufficient conditions. The finite lifetime of the immobilized biocatalyst has also a practical consequence, namely, the need of a regular biocatalyst replacement, for example, during the continuous operation of an immobilized cell bioreactor.

\section{Acknowledgment}

Financial support from FCT (Fundação para a Ciência e a Tecnologia, SFRH/BPD/3541/2000, Portugal) is gratefully acknowledged.

\section{References and Notes}

(1) Smit, G.; Straver, M. H.; Lugtenberg, B. J. J.; Kijne, J. W. Flocculence of Saccharomyces cerevisiae Cells Is Induced by Nutrient Limitation, with Cell Surface Hydrophobicity as a Major Determinant. Appl. Environ. Microbiol. 1992, 58, 3709-3714.

(2) Bowen, W. R.; Cooke, R. J. Studies of Saccharomyces cerevisiae during Fermentation-An in Vivo Electrokinetic Investigation. Biotechnol. Bioeng. 1989, 33, 706-715.

(3) Boonaert, CJ. P.; Dupont-Gillain, C. C.; Dengis, P. B.; Dufrene, Y. F.; Rouxhet, P. G. Cell Separation, Flocculation. In Encyklopedia of Bioprocess Technology: Fermentation, Biocatalysis and Bioseparation; Flickinger, M. C., Drew, S. W., Eds.; John Wiley \& Sons: New York, 1999; pp 531-548.

(4) Bowen, W. R.; Lovitt, R. W.; Wright, C. J. Atomic Force Microscopy Study of the Adhesion of Saccharomyces cerevisiae. J. Colloid. Interface Sci. 2001, 237, 54-61.

(5) Speers, R. A.; Smart, K.; Stewart, R. J. Zymolectins in Saccharomyces cerevisiae. J. Inst. Brew. 1998, 104, 298.

(6) Jin, Y. L.; Ritcey, L. L.; Speers, R. A. Effect of Cell Surface Hydrophobicity, Charge, and Zymolectin Density on the Flocculation of Saccharomyces cerevisiae. J. Am. Soc. Brew. Chem. 2001, 59, 1-9.

(7) Brányik, T.; Vicente, A.; Oliveira, R.; Teixeira, J. Physicochemical Surface Properties of Brewing Yeast Influencing Their Immobilization onto Spent Grains in a Continuous Reactor. Biotechnol. Bioeng. 2004, in press.

(8) Reynolds, T. B.; Fink, G. R. Bakers' Yeast, a Model for Fungal Biofilm Formation. Science 2001, 291, 878-881.

(9) Vernhet, A.; Bellon-Fontaine, M. N. Role of Bentonites in the Prevention of Saccharomyces cerevisiae Adhesion to Solid Surfaces. Colloids Surf., B 1995, 3, 255-262.

(10) Brányik, T.; Vicente, A. A.; Machado Cruz, J. M.; Teixeira, J. A. Spent Grains-A New Support for Brewing Yeast Immobilization. Biotechnol. Lett. 2001, 23, 1073-1078.

(11) Van Iersel, M. F. M.; Brouwer-Post, E.; Rombouts, F. M.; Abee, T. Influence of Yeast Immobilization on Fermentation and Aldehyde Reduction during the Production of AlcoholFree Beer. Enzyme Microb. Technol. 2000, 26, 602-607.

(12) Zhou, P.; He, J. H.; Qian, Y. Biofilm Airlift Suspension Reactor Treatment of Domestic Wastewater. Water, Air, Soil Pollut. 2003, 144, 81-100.

(13) Lee, K. C.; Rittmann, B. E. Applying a Novel Autohydrogenotrophic Hollow-fiber Membrane Biofilm Reactor for Denitrification of Drinking Water. Water Res. 2002, 36, 20402052.

(14) Tzeng, J. W.; Fan, L. S.; Gan, Y. R.; Hu, T. T. Ethanol Fermentation using Immobilized Cells in a Multistage Fluidized Bed Bioreactor. Biotechnol. Bioeng. 1991, 38, 1253-1258.

(15) Karel, S. F.; Libicki, S. B.; Robertson, C. R. The Immobilization of Whole Cells: Engineering Principles. Chem. Eng. Sci. 1985, 40, 1321-1354.

(16) Dale, M. C.; Chen, C.; Okos, M. R. Cell Growth and Dead Rates as Factors in the Long-term Performance, Modelling and Design of Immobilized Cell Reactors. Biotechnol. Bioeng. 1990, 36, 983-992.

(17) Gjaltema, A.; van der Marel, N.; van Loosdrecht, C. M.; Heijnen, J. J. Adhesion and Biofilm Development on Suspended Carriers in Airlift Reactors: Hydrodynamic Conditions Versus Surface Characteristics. Biotechnol. Bioeng. 1997, $55,880-889$

(18) Lewandowski, Z.; Altobelli, A. S.; Fukushima, E. NMR and Microelectrodes Studies of Hydrodynamics and Kinetics in Biofilms. Biotechnol. Prog. 1993, 9, 40-45.

(19) Junter, G. A.; Coquet, L.; Vilain, S.; Jouenne, T. Immobilized-cell Physiology: Current Data and the Potentialities of Proteomics. Enzyme Microb. Technol. 2002, 31, 201212.

(20) Baker, M. G.; Smart, K. A. Morphological Changes Associated with the Cellular Aging of a Brewing Yeast Strain. J. Am. Soc. Brew. Chem. 1996, 54, 121-126.

(21) Powell, C. D.; van Zandycke, S. M.; Quain, D. E.; Smart, K. A. Replicative Aging and Scenescence in Saccharomyces cerevisiae and the Impact on Brewing Fermentation. Microbiology 2000, 146, 1023-1034. 
(22) Li, J. K.; Asali, E. C.; Humphrey, A. E.; Horvath, J. J. Monitoring Cell Concentration and Activity by Multiple Excitation Fluorometry. Biotechnol. Prog. 1991, 7, 21-27.

(23) Horvath, J. J.; Glazier, S. A.; Spangler, C. J. In Situ Fluorescence Cell Mass Measurements of Saccharomyces cerevisiae Using Cellular Tryptophan. Biotechnol. Prog. 1993, $9,666-670$.

(24) Marose, S.; Lindemann, C.; Scheper, T. Two-Dimensional Fluorescence Spectroscopy: A New Tool for On-Line Bioprocess Monitoring. Biotechnol. Prog. 1998, 14, 63-74.

(25) Brányik, T.; Vicente, A. A.; Machado Cruz, J. M.; Teixeira, J. A. Continuous Primary Beer Fermentation with Brewing Yeast Immobilized on Spent Grains. J. Inst. Brew. 2002, 108, $410-415$.

(26) Brányik, T.; Vicente, A. A.; Machado Cruz, J. M.; Teixeira, J. A. Continuous Primary Fermentation of Beer with Yeast Immobilized on Spent Grains-The Effect of Operational Conditions. J. Am. Soc. Brew. Chem. 2004, 62, 29-34.

(27) Virkajärvi, I.; Kronlöf, J. Long-term Stability of Immobilized Yeast Columns in Primary Fermentation. J. Am. Soc. Brew. Chem. 1998, 56, 70-75.

(28) Tata, M.; Bower, P.; Bromberg, S.; Duncombe, D.; Fehring, J.; Lau, V.; Ryder, D.; Stassi, P. Immobilized Yeast Bioreactor Systems for Continuous Beer Fermentation. Biotechnol. Prog. 1999, 15, 105-113.

(29) Podrazký, O.; Kuncová, G.; Krasowska, A.; Sigler, K. Monitoring the Growth and Stress Responses of Yeast Cells by Two-dimensional Fluorescence Spectroscopy: First Results. Folia Microbiol. 2003, 48, 189-192.

(30) Kwong, S. C. W.; Rao, G. Metabolic Monitoring by Using the Rate of Change of $\mathrm{NAD}(\mathrm{P}) \mathrm{H}$ Fluorescence. Biotechnol. Bioeng. 1994, 44, 453-459.

(31) Maskell, D. L.; Kennedy, A. I.; Hodgson, J. A.; Smart, K. A. Impact of Carbohydrate Composition of Media on Lager Yeast Replicative Lifespan. J. Am. Soc. Brew. Chem. 2001, 59, 111-116.

(32) Sonnleitner, B.; Käppeli, O. Growth of Saccharomyces cerevisiae Is Controlled by its Limited Respiratory Capacity: Formulation and Verification of a Hypothesis. Biotechnol. Bioeng. 1986, 28, 927-937.
(33) Zeng, A. P.; Deckwer, W. D. A Kinetic Model for Substrate and Energy Consumption of Microbial Growth under Substrate-Sufficient Conditions. Biotechnol. Prog. 1995, 11, 7179

(34) Vicente, A. A.; Dluhý, M.; Teixeira, J. A. Increase of Ethanol Productivity in an Airlift Reactor with a Modified Draught Tube. Can. J. Chem. Eng. 1999, 77, 497-502.

(35) Vicente, A. A.; Dluhý, M.; Ferreira, E. C.; Teixeira, J. A. Modelling Diffusion-reaction Phenomena in Yeast Flocs of a Saccharomyces cerevisiae. Bioprocess Eng. 1998, 18, 335-342.

(36) Tsai, S. P.; Lee, Y. H. A Model for Energy-sufficient Culture Growth. Biotechnol. Bioeng. 1990, 35, 138-145.

(37) Horn, H.; Reiff, H.; Morgenroth, E. Simulation of Growth and Detachment in Biofilm Systems under Defined Hydrodynamic Conditions. Biotechnol. Bioeng. 2003, 81, 607-617.

(38) Wanner, O.; Gujer, W. A Multispecies Biofilm Model. Biotechnol. Bioeng. 1986, 28, 314-328.

(39) Van Benthum, W. A. J.; Garrido-Fernández, J. M.; Tijhuis, L.; van Loosdrecht, M. C. M.; Heijnen, J. J. Formation and Detachment of Biofilms and Granules in Nitrifying Biofilm Airlift Suspension Reactor. Biotechnol. Prog. 1996, 12, 764772 .

(40) Stewart, S. P. A Model of Biofilm Detachment. Biotechnol. Bioeng. 1993, 41, 111-117.

(41) Picioreanu, C.; van Loosdrecht, M. C. M.; Heijnen, J. J. Two-dimensional Model of Biofilm Detachment Caused by Internal Stress from Liquid Flow. Biotechnol. Bioeng. 2001, $72,205-218$.

(42) Melo, L. F.; Vieira, M. J. Physical Stability and Biological Activity of Biofilms under Turbulent Flow and Low Substrate Concentration. Bioprocess Eng. 1999, 20, 363-368.

(43) Michaud, S.; Bernet, N.; Roustan, M.; Delgenes, J. P. Influence of Hydrodynamic Conditions on Biofilm Behaviour in a Methanogenic Inverse Turbulent Bed Reactor. Biotech nol. Prog. 2003, 19, 858-863.

Accepted for publication August 12, 2004.

BP049766J 